\title{
A unidade dos contrários: fordismo e pós-fordismo*
}

\author{
Fernando G. Tenório**
}

Sumário: 1. Introdução; 2. Taylorismo-fordismo; 3. Pós-fordismo; 4. Conclusão.

Summary: 1. Introduction; 2. Taylorism-Fordism; 3. Post-Fordism; 4. Conclusion.

Palavras-chave: fordismo; pós-fordismo.

Key wORDs: Fordism; Post-Fordism.

Alguém que "nessa altura do campeonato", início de século XXI, escreve sobre taylorismo, fordismo e quejandos ou tem nostalgia do passado ou não tem atualizado seus conhecimentos. Melhor, é um antiquado, um matusalênico que pensa que o sistema ainda é de base mecânica quando a eficiência era contabilizada através do cronômetro, de movimentos previamente estabelecidos sobre um processo que corria por meio de roldanas e outros mecânicos meios. No entanto, não é esta impressão que propomos no presente artigo. Aqui o que objetivamos é resgatar conceitos que o modismo da contemporaneidade flexível não permite que sejam percebidos, escondendo indicadores da permanência de um fazer fordista travestido, muitas vezes, de moderno, atual. A tese proposta é que o pós-fordismo contém o fordismo. Ou seja, o fordismo não é substituído pelo pós-fordismo, visto que este último contém, de acordo com a unidade dos contrários, lei da dialética, elementos fordistas, substâncias que serão representadas por meio de um continuum. Assim, a aparente situação antitética não ocorre uma vez que o pós-fordismo compreende seu oposto, o fordismo.

\section{The unity of oposites: Fordism and Post-Fordism}

Someone who, "at this stage of the game," in the early twenty-first century, is writing about Taylorism, Fordism and the like is either nostalgic of the past or has not been updating his knowledge. Better still, he is an old-fashioned, methuselah-ish type who thinks the system is still mechanically based, as in the days when efficiency was measured with a stopwatch, its motion previously set on a process that ran through

\footnotetext{
* Artigo recebido em fev. 2010 e aceito em nov. 2010.

** Professor titular na Escola Brasileira de Administração Pública e de Empresas (Ebape) da Fundação Getulio Vargas (FGV) e pesquisador do CNPq (Conselho Nacional de Pesquisa). Praia de Botafogo, 190/5o andar - Botafogo - CEP 22250-900, Rio de Janeiro, RJ, Brasil. E-mail: Fernando.tenorio@fgv.br.
} 
pulleys and other mechanical means. However, this is not the impression we propose in this article. Our aim is to recover concepts that flexible contemporary trendiness will not allow to be perceived as it hides indicators of permanence of Fordist operation ways, often disguised as modern, current ways. This study proposes that post-Fordism contains Fordism. In other words, Fordism is not replaced by post-Fordism, since the latter, according to the dialectic law of unity of opposites, contains Fordist elements, substances represented in a continuum. Therefore, the apparently antithetical situation does not occur, since post-Fordism includes its opposite, Fordism.

A ambiguidade é a manifestação imagética da dialética [...]. Tal imagem é representada também pela prostituta, que é vendedora e mercadoria numa só pessoa (Benjamin, 2006:48).

\section{Introdução}

Parece ser que a lei dialética da unidade dos contrários começa com Heráclito de Éfeso (século VI-V a.C.) ${ }^{1}$ ao enunciar, por meio de um de seus fragmentos, ${ }^{2}$ que "o contrário é convergente e dos divergentes nasce a mais bela harmonia, e tudo segundo a discórdia" (Souza, 1973:86). Do V século a.C. chegamos ao XIX d.C. com Georg Wilhelm Friedrich Hegel (1770-1831) ${ }^{3}$ ao dizer que "não existe frase de Heráclito que eu não tenha integrado em minha Lógica" (Souza, 1973:98). "Heráclito também diz que os opostos são características do mesmo, [...], ser e não ser ligam-se ao mesmo" uma vez que o "infinito, que é em si e para si, é a unidade dos opostos e, na verdade, dos universalmente opostos, da pura oposição, ser e não ser" (Souza, 1973:99). Conclui Hegel: "Heráclito expressou de modo determinado este pôr-se numa unidade das diferenças" (Souza, 1973:99). "Saber que na unidade se encontra a contradição e na contradição

\footnotetext{
1 "Considerado o filósofo do devir, do vir-a-ser, do movimento, o grego (nascido em Éfeso) Heráclito é o mais importante pré-socrático" (Japiassu e Marcondes, 1990:117).

2 "Eis agora o mais extraordinário dos 'pré-socráticos'. Da Antiguidade até os nossos dias ele foi compreendido nos sentidos mais divergentes; resta-nos hoje de seu livro menos de cento e trinta fragmentos de uma a cinco linhas" (Châtelet, 1973:34).

3 "O mais importante filósofo do idealismo alemão pós-kantiano e um dos filósofos que mais influenciou o pensamento de sua época e o desenvolvimento posterior da filosofia, Hegel nasceu em Stuttgart, na Alemanha, estudou filosofia na Universidade de Tübingen e foi professor nas Universidades de Iena (1801-1806), Heidelberg (1816-1818) e Berlim (1818-1831), chegando a reitor desta última." (Japiassu e Marcondes, 1990:115, grifos do autor).
} 
a unidade, eis o saber absoluto; e a ciência consiste em conhecer por si mesma esta unidade no seu desenvolvimento global" (Hegel apud d'Hondt, 1984:88). ${ }^{4}$ Portanto, partindo destes supostos heraclitiano e hegeliano, entendemos que o pós-fordismo, apesar de sua aparência antitética, contém o fordismo, isto é, que o conceito de pós-fordismo compreende seu oposto, o fordismo.

Ao que parece, o surgimento do paradigma técnico pós-fordista, referência das recentes técnicas de gestão organizacional, propõe criar mecanismos no espaço das interações sociais. Técnicas integradas de produção que não só atendam às diferentes demandas do ambiente operacional das empresas, mas também sugerem promover condições democratizadoras nas relações sociais no interior das organizações. Com a finalidade de analisar esta proposição conceitual desenvolveremos este texto por meio de dois tópicos: no primeiro caracterizaremos o fordismo como um modelo microeconômico que surge no início do século XX e se estende também como modelo macroeconômico até os anos 1970, e cuja substância social é determinada pela técnica; no segundo caracterizaremos o aparecimento do pós-fordismo como paradigma do final do século XX, na medida em que ele se tornou "um compromisso social, aceito - por bem ou por mal - pelos dirigentes e trabalhadores" (Leborgne e Lipietz, 1991:102), e cuja substância social seria determinada não mais exclusivamente pela técnica, mas pela interação dos envolvidos no processo.

As expressões fordismo e pós-fordismo, da mesma forma que modernidade e pós-modernidade, sociedade industrial e pós-industrial, estado de bem-estar social e neoliberalismo, têm gerado debates a respeito da validade ou não desses conceitos. Apesar disso, vamos utilizar esses pares como conceitos que são representados como antitéticos: fordismo versus pós-fordismo. Procurando manter coerência com a lei da unidade dos contrários, o processo de produção contemporâneo ocorreria sob o continuum: fordismo (0) (1) pós-fordismo. ${ }^{5}$ Nesse espaço, várias possibilidades ou combi-

\footnotetext{
4 "Hegel busca apoiar-se em diversos exemplos triviais: embaixo e em cima, direito e esquerdo, pai e filho, e fala em Gegensatz e Entgegensetzung - em contraposição. Direito é o que não é esquerdo, e só se determina enquanto não é esquerdo; o direito só é na medida em que o esquerdo é, e vice-versa. O pai é outro que não o filho, e o filho é outro que não o pai; pai e filho só são enquanto são 'esse outro do outro'. Sem a relação com o filho, o pai é simplesmente um homem: ao ser-pai pertence o ser-filho. Ou ainda: o pai é na medida em que ele não é filho, mas esse não ser filho revela-se essencial para que o pai seja pai. Assim, a negatividade pertence ao ser, e a validez da reflexão repousa precisamente nesse "aprender e expressar a contradição"' (Bornheim, 1977:282).

${ }^{5}$ Fixar a discussão entre dois pontos de um continuum significa trabalhar uma unidade dialética entre a continuidade e a descontinuidade. Isto é, na especificidade desse tema, fordismo-pós-
} 
nações tecnológicas poderiam ocorrer, porém nunca absolutamente fordistas nem pós-fordistas. Exemplar para esta possibilidade é a expressão "fábrica de software" empregada naquelas empresas produtoras de programas computadorizados. A fim de dicotomizar os significados de fordismo e pós-fordismo, trabalharemos com cinco argumentos:

a) utilizaremos o conceito de fordismo como semelhante à rigidez organizacional e de pós-fordismo como semelhante à flexibilização organizacional, ambos como paradigmas técnico-gerenciais cuja periodização vai dos anos 1910 ao final dos anos 1960 - fordismo —, e dos anos 1970 aos dias de hoje - pós-fordismo. Essa periodização pode corresponder ao manuseio de máquinas-ferramentas (automação rígida) versus operacionalização de máquinas eletrônicas (automação flexível);

b) utilizaremos o conceito de fordismo para caracterizar o "gerenciamento tecnoburocrático de uma mão de obra especializada sob técnicas repetitivas de produção de serviços ou de produtos padronizados" (Tenório e Palmeira, 2008:61); e pós-fordismo ou modelo flexível de gestão organizacional para caracterizar a diferenciação integrada da organização da produção e do trabalho sob a trajetória de inovações tecnológicas em direção à democratização das relações sociais nas organizações;

c) utilizaremos o conceito de fordismo, sob o ponto de vista da história do pensamento organizacional, para aquelas teorias ou enfoques organizacionais que, desde a publicação, em 1911, de Principles of scientific management de F. W. Taylor, ${ }^{6}$ divulgam suas propostas na perspectiva de as organizações atuarem como sistemas mecânicos; e pós-fordismo quando as organizações passam a ser estudadas como sistemas orgânicos, simultaneamente ao advento do modelo gerencial japonês (toyotismo anos 1970) e, principalmente, com a intensificação do uso da tecnologia de base microeletrônica.

Apesar de o conceito de fordismo ser aplicado sob duas possibilidades: na primeira, mais genérica, o fordismo como uma manifestação de uma de-

fordismo, estas atuariam, dialeticamente, sob um continuum, no qual práticas fordistas permanecem apesar de o trabalho ser, predominantemente, de natureza imaterial e não material como nas fábricas tradicionais. Assim, "entre um e outro ponto, as transições seriam mais sutis, e não excluiria a inspiração de uma pelas outras” (Vergara e Caldas, 2005:71).

${ }^{6}$ Originalmente editado em Nova York, por Harper \& Bros, em 1911. No Brasil foi publicado em 1948: TAYLOR, Frederick Winslow. Princípios de administração científica. Rio de Janeiro: Presidência da República-Dasp, 1948. 
terminada etapa do capitalismo; na segunda, mais específica, o fordismo seria a operacionalização de um modelo de gestão da produção. Neste ensaio descreveremos o fordismo como um paradigma de organização da produção e do trabalho e não como uma referência de organização socioeconômica de sociedades.

\section{Taylorismo-fordismo}

Descrever o fordismo como paradigma de organização da produção e do trabalho não mencionando o taylorismo é relatar, parcialmente, este paradigma uma vez que o fordismo tem uma relação quase que umbilical com o taylorismo. ${ }^{7} \mathrm{Na}$ realidade, historicamente, antes de Taylor e Ford, outros momentos e outros autores contribuíram para o desenvolvimento de formas de gestão organizacional. Um texto clássico da literatura econômica mundial e que contribui para reforçar a ideia de que antes de Taylor já se escrevia sobre formas gerencias de produção é o livro de Adam Smith (1723-90), A riqueza das nações, publicado em 1776 . No Livro Primeiro desse texto, Smith discute a divisão do trabalho dando como exemplo o já conhecido caso da fábrica de alfinetes:

Tomemos, pois, um exemplo, tirado de uma manufatura muito pequena, mas na qual a divisão do trabalho muitas vezes tem sido notada: a fabricação de alfinetes. Um operário não treinado para essa atividade [...] nem familiarizado com a utilização das máquinas ali empregadas [...], dificilmente poderia talvez fabricar um único alfinete em um dia, [...]. Entretanto, da forma como essa atividade é hoje executada, não somente o trabalho todo constitui uma indústria específica, mas ele está dividido em uma série de setores, [...]. Um operário desenrola o arame, um outro o endireita, um terceiro o corta, um quarto faz as pontas, um quinto o afia nas pontas para a colocação da cabeça do alfinete; [...]. Assim, a importante atividade de fabricar um alfinete está dividida em aproximadamente 18 operações distintas, as quais, em algumas manufaturas, são executadas por pessoas diferentes, [...] parte daquilo que hoje são capazes de produzir, em virtude de uma adequada divisão do trabalho e combinação de suas diferentes operações (Smith, 1983:41-42).

\footnotetext{
${ }^{7}$ Autores como Benedito Rodrigues de Moraes Neto apontam que o fordismo deve ser entendido "como desenvolvimento da proposta taylorista" (Moraes Neto, 1989:35).
} 
No século XIX, mais precisamente em 1832, Charles Babbage escreveu On the economy of machinery and manufactures, que incluía ideias sobre divisão do trabalho, organogramas e relações de trabalho. Segundo Harry Braverman (1977:85), Babbage "foi talvez o mais direto precursor de Taylor, que deve ter sido frequentador da obra de Babbage, muito embora jamais se tenha referido a ele".

Sem nos determos em fatos históricos ou em autores que ao longo dos séculos pontuaram ou exerceram uma possível influência sobre o processo de gestão organizacional, visto que vários textos já foram publicados sobre o assunto, ${ }^{8}$ faremos um corte na historiografia do pensamento gerencial no final do século XIX, momento da publicação da primeira obra de Taylor, ${ }^{9}$ o real precursor do pensamento gerencial contemporâneo. Afirmação que é confirmada por autores como Braverman, que utiliza uma citação de Lyndall Urwick e de E.F.L. Brech (divulgadores do taylorismo, segundo Braverman) para reforçar essa ideia: "O que Taylor fez não foi criar algo inteiramente novo, mas sintetizar e apresentar ideias num todo razoavelmente coerente que germinaram e ganharam força na Inglaterra e nos Estados Unidos durante o século XIX. Ele deu uma filosofia e título a uma série desconexa de iniciativas e experiências" (Braverman, 1977:85).

Dos textos elaborados por Taylor, aquele que o faz conhecido e tornouse um marco na história do pensamento gerencial foi, sem dúvida, Principles of scientific management (1948). O objetivo central desse livro foi divulgar a compreensão que Taylor tinha sobre gestão empresarial. Suas experiências como aprendiz, operário, capataz, contramestre, chefe de oficina e engenheiro $^{10} \mathrm{o}$ põem em contato direto com os problemas sociais e empresariais origi-

\footnotetext{
${ }^{8}$ É grande a bibliografia estrangeira e nacional sobre o tema. Como introdução cito, entre outros, apenas alguns textos publicados por autores brasileiros. Lodi (1971); Chiavenato (1979); Motta (1979); Wahrlich (1983); Motta, (1986); Caravantes (1998).

${ }^{9} \mathrm{O}$ primeiro texto foi A note on belting (Notas sobre as correias), apresentado em 1895, quando Taylor ingressa na American Society of Mechanical Engineers (Asme); o segundo, A piece-rate system (Um sistema de gratificação por preço), também de 1895, é exposto na mesma Asme. O terceiro foi Shop management (Administração de oficinas), publicado em Nova York, pela Harper \& Bros, em 1903. Além dessas publicações, Taylor registrou cerca de 50 patentes de invenções sobre máquinas, ferramentas e processos de trabalho.

${ }^{10}$ Taylor inicia "sua carreira na Enterprise Hydraulic Works, onde ingressou como aprendiz. Posteriormente passou a trabalhar na Midvale Steel Company, onde começou como operário especializado, galgando rapidamente posições que o tornaram engenheiro-chefe de oficinas. Taylor trabalhou ainda na Manufacturing Investmente Co. e na Bethlehem Steel Co., caracterizando-se por uma vida profissional totalmente voltada para a iniciativa privada. Foi também consultor
} 
nados pela segunda Revolução Industrial, momento do surgimento das máquinas-ferramentas (M-F).${ }^{11}$ Esses elementos biográficos ${ }^{12}$ sistematizam ideias em um contexto nacional (Estados Unidos da América - EUA, uma potência emergente do capitalismo industrial em substituição à Inglaterra) e empresarial (não podemos esquecer desde já que, com exceção principalmente das técnicas ou da "onda" gerencial japonesa de final do século $\mathrm{XX}$, as tecnologias e formas de gerenciamento da produção no Brasil têm, em sua maioria, origem nos EUA) que tinha como antecedente administrar sua produção através de contratos com artífices ou grupos de operários especializados em determinado segmento da produção. ${ }^{13}$

O taylorismo contribuiu para essa nova forma de gestão na medida em que a concentração técnica permitiu, através das M-Fs, utilizar mão de obra não necessariamente capacitada, como era o caso dos contratados ou dos trabalhadores de ofício que desempenhavam suas tarefas a partir de um conhecimento tácito e até consuetudinário. Agora, com as M-Fs, o trabalhador seria treinado sob o princípio do one best way ("melhor gesto") para desem-

de várias empresas e frequentemente proferia conferências em estabelecimentos industriais e universidades" (Wahrlich, 1983:301).

${ }^{11}$ Anteriormente às M-Fs existiam os tornos, equipamentos rudimentares que faziam girar as peças a serem trabalhadas: era o próprio operário que segurava o material para dar-lhes forma; regulava a pressão, o ângulo de corte, a profundidade do mesmo, orientando-se por suas reações táteis e sua observação visual; o conhecimento direto do material era um fator decisivo. As máquinas-ferramentas, também denominadas máquinas operatrizes, são modernização dos tornos na medida em que a elas são incorporadas ferramentas destinadas à realização de qualquer trabalho de acabamento mecânico. Exemplos de M-Fs são as presas, tesouras, martelo, punções, fresadoras, plainas etc. Além de provocar a reorganização do processo de produção, as M-Fs facilitam a admissão de trabalhadores não especializados (Vergara, 1971:27). São, em síntese, "dispositivos relativamente complexos, elas integram várias ferramentas diferentes e podem - mediante a aplicação de operações sucessivas - desenvolver um programa que permite efetuar tarefas finalmente complexas de transformação das matérias" (Coriat, 1993:40).

${ }^{12}$ Um dos traços biográficos reconhecidos em Taylor, segundo Harry Braverman, era sua exagerada "personalidade obsessivo-compulsiva" em busca de eficiência que o levava a analisar movimentos pessoais, como o número de passos que ele dava em determinada atividade. Ainda de acordo com Braverman, citando Sudhir Kakar, Taylor era, "no mínimo, maníaco neurótico" (Braverman, 1977:87). A vida e a obra de Taylor poderão ser melhor exploradas em Kanigel (1997).

13 "Especialmente nestes primórdios, o conteúdo do trabalho não tinha nada de capitalista. Por sinal, o total controle do trabalhador sobre suas atividades de ofício (habilidades, conhecimentos práticos, informações objetivas sobre o processo de trabalho), características do que se chamou acima de base técnica artesanal, era um obstáculo para os objetivos dos capitais produtivos que iam se formando, no que diz respeito ao aumento da sua valorização. O oficial artesão determinava seu ritmo de trabalho e, logo, controlava sua produtividade" (Castro et al., 1996:26). 
penhar determinada tarefa em um determinado tempo junto à máquina. ${ }^{14} \mathrm{O}$ conteúdo do trabalho dessa nova mão de obra não ficou restrito ao operário especializado ou semiespecializado do "chão de fábrica", mas disseminou-se nas tarefas burocráticas tanto do setor secundário quanto do terciário da economia. Exemplos são os datilógrafos, tipógrafos e mecanógrafos que tinham seus desempenhos avaliados pelos números de toques dados nas máquinas de datilografar, de tipografia ou de fichas preenchidas nas máquinas contábeis. ${ }^{15}$ A proposta do taylorismo para o one best way, a análise e definição de como melhor executar a tarefa, pode ser resumida da seguinte forma:

- definição exata dos movimentos elementares necessários para executar o trabalho e das ferramentas e materiais utilizados;

- determinação por cronometragem, ou outros métodos de medida, dos tempos necessários para executar cada um desses movimentos;

— análise dos movimentos para conseguir sua simplificação e a maior economia de gestos;

— reunião dos movimentos em uma sequência que constitui uma unidade de tarefa (Durand, 1978:50).

As ideias de Taylor não ficaram restritas ao processo operacional ou, como muitos acreditam, ao estudo de tempos e movimentos. ${ }^{16}$ Seu enfoque e intenção, quando da publicação dos Princípios de administração científica, foi definir a administração como um conhecimento sistematizado e abrangente. $\mathrm{Na}$ introdução ao livro, Taylor apresentou três objetivos dos quais reproduziremos o terceiro:

\footnotetext{
14 "Através de quadros que associam microgestos a microtempos, os engenheiros e os técnicos dos métodos juntam perfis de tarefas correspondentes a uma agregação de alguns microgestos, aos quais são imediata e diretamente associados tempos de operação" (Coriat, 1994:67).

15 "A sua 'capacidade de inovar' permitiu também que seus métodos fossem difundidos para outros setores: vendas, finanças, escritórios e administração de pessoal” (Heloani, 1994:42).

${ }^{16}$ Fred E. Meyers diz que Taylor "é conhecido como o pai da administração científica e da engenharia industrial. Ele foi a primeira pessoa a usar um cronômetro para estudar o conteúdo do trabalho e, como tal, é chamado o Pai do Estudo de Tempo" (Meyers, 1992:7). No entanto, segundo ainda Meyers, foi o casal "Frank (1868-1924) e Lílian Gilbreth (1878-1972) que são conhecidos como os pais do estudo de movimentos", publicando, em 1911, o livro Time and motion study (Meyers, 1992:9). O casal Gilbreth introduziu, no processo de produção, a noção de micromovimentos analisados através de câmera de cinema. Antes dos Gilbreths, porém, o primeiro estudo sobre cálculos de precisão para produção foi feito em 1833, numa oficina em Manchester (Inglaterra), pelo engenheiro-mecânico Joseph Whitworth (1803-87), Oxford Dictionary of National Biography. Disponível em: <www.oxforddnb.com>. Acesso em: 3 maio 2011.
} 
TERCEIRO - Para provar que a melhor administração é uma verdadeira ciência, regida por normas, princípios e leis claramente definidos, tal como uma instituição. Além disso, para mostrar que os princípios fundamentais da administração científica são aplicáveis a todas as espécies de atividades humanas, desde nossos atos mais simples até o trabalho nas grandes companhias que reclama a cooperação mais apurada. E, em resumo, para convencer o leitor por meio duma série de argumentos de que, corretamente aplicados estes princípios, os resultados serão verdadeiramente assombrosos (Taylor, 1948:12).

O enfoque de Taylor não estava restrito, como já observamos, à análise de tarefas, mas ao desenvolvimento de uma sistematização de ideias que vai da organização da produção à organização do trabalho. Vejamos a primeira frase do capítulo 1 do livro Princípios de administração científica: "O principal objetivo da Administração deve ser assegurar o máximo de prosperidade ao patrão e, ao mesmo tempo, o máximo de prosperidade ao empregado" (Taylor, 1948:13). Teoricamente, portanto, ele se preocupou tanto com o capitalista e seus resultados como investidor quanto com o operário e seu bem-estar. No entanto, apesar dessa intenção, a história tem demonstrado que no tocante ao trabalhador, notadamente àqueles de nível operacional ou de "chão de fábrica", o bem-estar tem passado ao largo do ideal taylorista. ${ }^{17}$

A análise da repercussão, a favor e contra, ${ }^{18}$ do pensamento de Taylor ${ }^{19}$ — sem fazer referência a autores que complementaram sua obra nem ao tra-

\footnotetext{
${ }^{17}$ A expressão "trabalhador" aqui é usada de forma indistinta, tanto pode ser aquele do "chão de fábrica" quanto o de escritório; o que tipifica esta categoria social é o fato de o indivíduo ser assalariado e atuar sob um "contrato ou acordo que estabelece as condições da venda da força de trabalho pelo trabalhador e sua compra pelo empregador" (Braverman, 1977:55).

${ }^{18}$ Um texto que se tornou clássico no estudo crítico ao taylorismo é o de Braverman (1977). No setor das artes, dois filmes destacaremos: Tempos modernos (1936), de Charles Chaplin, é um exemplo contudente de crítica às propostas de Taylor; A classe operária vai ao paraíso (1971), de Elio Petri, Palma de Ouro em Cannes, retrata a permanência do modelo taylorista de produção ainda nos anos 1970. Vale lembrar também que o Congresso americano criou, em 1911, uma comissão especial chamada de investigação Hoxie, professor da Universidade de Chicago, para analisar as ideias de Taylor. As conclusões foram críticas ao modelo taylorista. Ver Braverman (1977:88); Heloani (1994:33-6); Leite (1994:59-73); Vergara (1971:15); Coriat (1994:115) e Guerreiro Ramos (2009:53).

${ }^{19}$ Apesar da ácida crítica que Harry Braverman faz ao taylorismo, ele reconhece a importância da obra de Taylor para a gestão empresarial: "É impossível superestimar a importância do movimento da gerência científica no modelamento da empresa moderna e, de fato, de todas as instituições da sociedade capitalista que executam processos de trabalho. A noção de que o taylorismo foi 'superado' [...] representa lamentável má interpretação da verdadeira dinâmica do desenvolvimento da
} 
balho de pensadores coetâneos com o movimento da administração científica, caso do francês Henry Fayol, que publica em 1916 Administration industrielle et générale $-{ }^{20}$ não se esgota em poucas páginas. ${ }^{21}$

Ao que parece, no Brasil o taylorismo entrou por dois caminhos: o privado e o público. A confirmar essa possibilidade está o livro de Beatriz Marques de Souza Wharlich, Reforma administrativa na era Vargas. Nesse texto a autora faz o seguinte comentário: "Já na criação do Conselho Federal do Serviço Público Civil (CFSPC), em 1936, mas mais diretamente na definição dos objetivos do Dasp, em 1938, há visíveis influências do movimento taylorista, que no Brasil possuía, desde 1931, seu órgão próprio, o Instituto de Organização Racional do Trabalho (Idort)" (Wahrlich, 1983:302). Em seguida, Beatriz Wahrlich complementa seu comentário citando a revista comemorativa do quinto aniversário (1936) do Idort: "Completa o primeiro lustro de existência o Instituto de Organização Racional do Trabalho, de São Paulo. Fundado em 1931, por um grupo de entusiastas capacitados da oportunidade de criação,

gerência (Braverman, 1977:83). Os princípios tayloristas foram também empregados na ex-URSS (União das Repúblicas Socialistas Soviéticas) logo após o triunfo da Revolução Bolchevique de 1917. Ver Heloani (1994:36-41) e Leborgne e Lipietz (1991:113). Jeffrey Herf, ao comparar o nazismo como o marxismo, diz: "tanto Lênin quanto subsequentemente o marxismo-leninismo tinham grande entusiasmo por ciência e tecnologia, mas sem o resíduo do irracionalismo filosófico que onerava o nacional-socialismo. [...] O entusiasmo de Lênin pelo taylorismo é manifestação, uma apenas, da visão marxista-leninista de que o comunismo acontece como desdobramento das tendências tecnológicas e científicas de dentro do capitalismo" (Herf, 1993:248). András Hegedüs, ao analisar a NEP (Nova Política Econômica) adotada no início dos anos 1920 por Lênin na ex-URSS, diz: "A organização científica do trabalho - taylorismo, antes de tudo — adquiriu popularidade muito grande junto aos dirigentes soviéticos, o que fez de novo emergir a exigência da técnica e aumentou ao mesmo tempo a necessidade de ampliação dos aparelhos de direção especializada" (Hegedüs, 1986:40). Texto que amplia a análise da relação entre o taylorismo e leninista também pode ser observado em Finzi (1986:137-157).

${ }^{20}$ Segundo David Harvey, este livro de Fayol teve maior repercussão na Europa do que o de Taylor (Harvey, 1992:123). Não obstante esta observação, José M. Vergara diz que as ideias de Taylor entraram na Europa através da Inglaterra por volta de 1905 na fábrica J. Hopkinson e na França, em 1912, nas oficinas de Arbel Berliet e Ranault (Vergara, 1971:15). "Mesmo se sua posteridade teórica é bem menos solidamente estabelecida - e inventariada - Fayol, tanto quanto Taylor, é um dos fundadores da arte gerencial norte-americana e da constituição da empresa moderna. Como Taylor, mas a sua maneira e em seu próprio domínio, Fayol fez com que se realizasse um salto no saber-fazer de empresa" (Coriat, 1994:75). Benjamin Coriat identifica algumas contribuições de Fayol ao pensamento gerencial: definição do papel da direção geral de uma empresa e criação do organograma funcional (Coriat, 1994:75-76).

${ }^{21}$ Até agora o livro que melhor tem apresentado a biografia e o pensamento da Taylor é de Kanigel (1997). 
em nossa terra, de uma entidade destinada a propugnar pela aplicação dos princípios de organização científica do trabalho, [...]" (Wahrlich, 1983:302). Quanto ao setor público, diz a autora:

Na definição da competência do CFSPC evidencia-se a influência do taylorismo nas seguintes atribuições a ele conferidas pela Lei no 284, de 1936:

Art. 10:

a) estudar a organização dos serviços públicos e propor ao Governo qualquer medida necessária ao seu aperfeiçoamento;

$[\ldots]$;

i) opinar sobre propostas, normas e planos de racionalização de serviços públicos, elaborados pelas comissões de eficiência (Wahrlich, 1983:303).

\subsection{Fordismo}

O fordismo é um método de organização da produção e do trabalho complementar ao taylorismo "que se caracteriza pelo gerenciamento tecnoburocrático de uma mão de obra especializada sob técnicas repetitivas de produção de serviços ou de produtos padronizados" (Tenório, 1994:88). Como paradigma gerencial, o fordismo surge no setor secundário da economia e mais especificamente na indústria automobilística. Seu conteúdo é originado em uma fábrica de veículos, passando a fazer "escola" nos demais setores econômicos. ${ }^{22}$ Portanto, o fordismo é:

um princípio geral de organização da produção (compreendendo paradigma tecnológico, forma de organização do trabalho e estilo de gestão). Neste plano, podem ser destacados os seguintes traços característicos ou princípios constitutivos do paradigma fordista: a) racionalização taylorista do trabalho: profunda divisão - tanto horizontal (parcelamento das tarefas) quanto vertical (separação entre concepção e execução) - e especialização do trabalho; b) desenvolvimento da mecanização através de equipamentos altamente especializados; c) produção em massa de bens padronizados; d) a norma fordista de salários: salários relativamente elevados e crescentes - incorporando ganhos de pro-

\footnotetext{
${ }^{22}$ Até os dias de hoje as referências gerenciais modernizadoras quer no processo de produção industrial, quer de prestação de serviços são, em sua maioria, originalmente elaboradas na indústria automobilística.
} 
dutividade - para compensar o tipo de processo de trabalho predominante (Ferreira et al., 1991).

A indústria automobilística antes do fordismo produzia veículos através de uma organização da produção que dependia da habilidade da mão de obra envolvida. O processo era artesanal desde a etapa da elaboração do projeto até a sua execução e distribuição. A industrialização de veículos dependia de trabalhadores que conheciam detalhadamente os princípios de mecânica e os materiais com que trabalhavam. "Além do mais, muitos eram seus próprios patrões, muitas vezes trabalhando como empreiteiros independentes [...] o que era ainda mais frequente - proprietários independentes de instalações fabris às quais a companhia encomendava componentes ou peças específicas" (Womack et al., 1992:9-10). Em resumo, a produção de veículos era artesanal e possuía as seguintes características:

- Uma força de trabalho altamente qualificada em projeto, operação de máquinas, ajuste e acabamento. Muitos trabalhadores progrediam através de um aprendizado abrangendo todo um conjunto de habilidades artesanais. Muitos podiam esperar administrar suas próprias oficinas, tornando-se empreendedores autônomos trabalhando para firmas de montagem.

- Organizações extremamente descentralizadas, ainda que concentradas numa só cidade. A maioria das peças e grande parte do projeto do automóvel provinham de pequenas oficinas. O sistema era coordenado por um proprietário/empresário em contato direto com todos os envolvidos: consumidores, empregados e fornecedores.

- O emprego de máquinas de uso geral para realizar a perfuração, corte e demais operações em metal ou madeira.

- Um volume de produção baixíssimo, de 1 mil ou menos automóveis por ano, poucos dos quais (50 ou menos) conforme o mesmo projeto. E, mesmo entre estes 50, não havia dois que fossem idênticos, pois as técnicas artesanais produziam, por sua própria natureza, variações (Womack et al., 1992:12).

Como os autores de A máquina que mudou o mundo observam, esse tipo de produção, apesar de ainda existir para o atendimento de pequenos e sofisticados nichos de mercado, tem um custo unitário elevado se comparado ao de produção em massa implementado pelo fordismo. Neste, o custo unitário decresce conforme aumenta o volume de produção. Outra objeção diz respeito às diferenças de produtos resultantes desse processo artesanal. Fato que ocorria porque era usado "sistema de metrologia, e as máquinas-ferramentas dos anos 1890 eram incapazes de cortar aço com alta dureza" (Womack et al., 1992:10). 
Semelhante ao taylorismo, o fordismo como técnica de gestão da produção surgiu a partir das ideias de Henry Ford, que de mecânico a engenheiro-chefe e proprietário de fábrica adquire experiência suficiente para elaborar um método de produção que supere o de tipo artesanal. Entre 1892 e 1896 constrói um automóvel peça por peça. Em 16 de junho de 1903 fundou a Ford Motor Co., com aproximadamente 125 empregados, colocando à venda, em outubro do mesmo ano, o primeiro carro. Cinco anos depois produz o famoso Modelo T (no Brasil ficou conhecido como Ford Bigode), atingindo entre 1908 e 1926 o recorde em vendas de 15 milhões de unidades. Em 1913 sua empresa já fabricava 800 carros por dia e em 1926, 23 anos após a inauguração da Ford Motor Co., possuía 88 usinas e empregava 150 mil pessoas, fabricando então 2 milhões de carros por ano. Ford teve outros méritos além da produção em escala. A verticalização e a horizontalização do processo de produção, desde a matéria-prima à colocação do produto no mercado, contribuíram para o sucesso de suas propostas, enquanto organização da produção. Além do que estabeleceu alguns princípios básicos que são, até hoje, objeto de aplicação. ${ }^{23}$

Apesar de muitos atribuírem a Henry Ford somente a ideia da linha de montagem, ${ }^{24}$ foi, no entanto, a de produção em massa uma das principais con-

\footnotetext{
${ }^{23}$ 1. Princípio de intensificação: consiste em diminuir o tempo de produção com o emprego imediato dos equipamentos e da matéria-prima e a rápida colocação do produto no mercado; 2. Princípio de economicidade: consiste em reduzir ao mínimo o volume de estoque da matéria-prima em transformação. Por meio desse princípio, Ford conseguiu fazer com que o trator ou o automóvel fossem pagos a sua empresa antes de vencido o prazo de pagamento da matéria-prima adquirida, bem como do pagamento de salários; 3. Princípio de produtividade: consiste em aumentar a capacidade de produção do homem no mesmo período através da especialização e da linha de montagem. Assim, o operário pode ganhar mais, num mesmo período de tempo, e o empresário ter maior produção (Chiavenato, 1979:60). A intensificação e a produtividade sob o fordismo são bem exploradas por Dal Rosso (2008). Para Dal Rosso, intensificação são "os processos de quaisquer naturezas que resultam em um maior dispêndio das capacidades físicas, cognitivas e emotivas do trabalhador com o objetivo de elevar quantitativamente ou melhorar qualitativamente os resultados. Em síntese, mais trabalho" (Dal Rosso, 2008:23). Por sua vez, "intensidade e produtividade são conceitos diferentes com conteúdos distintos e que a noção de intensidade desvela o engajamento dos trabalhadores significando que eles produzem mais trabalho, ou trabalho de qualidade superior, em um mesmo período de tempo considerado e que a noção de produtividade restringe-se ao efeito das transformações tecnológicas" (Dal Rosso, 2008:29).

${ }^{24}$ Um sistema semelhante a linha de montagem foi empregado pela primeira vez no início do século XIX, na Marinha inglesa, para a produção de biscoitos. No entanto, foi a tecnologia de abatedouro de animais que inspirou Henry Ford, em 1870, a projetar sua primeira linha de montagem para produção de magnetos (Ritzer, 1993). Na indústria automobilística, o processo de produção por esteiras foi implantado em 1913 por Ford para a produção do Modelo T na sua fábrica de Highland Park, em Michigan (Hirschhorn, 1984:9).
} 
tribuições de Ford ${ }^{25}$ à organização da produção e do trabalho. A "chave para a produção em massa não residia - conforme muitas pessoas acreditavam ou acreditam - na linha de montagem em movimento contínuo. Pelo contrário, consistia na completa e consistente intercambialidade das peças e na facilidade de ajustá-las entre si. Essas foram as inovações na fabricação que tornaram a linha de montagem possível" (Womack et al., 1992:14, grifo dos autores). Portanto, o sistema pelo qual as peças circulam no interior da fábrica através de esteiras, evitando deslocar o operário do seu posto de trabalho. Em vez de o operário deslocar-se para ir buscar a peça, como se fazia no processo artesanal, com a linha de montagem o trabalhador espera a peça no seu posto de trabalho.

Nosso primeiro passo no aperfeiçoamento da montagem consistiu em trazer o trabalho ao operário ao invés de levar o operário ao trabalho. Hoje todas as operações se inspiram no princípio de que nenhum operário deve ter mais que um passo a dar; nenhum operário deve ter que se abaixar.

Os princípios da montagem são:

1. Trabalhadores e ferramentas devem ser dispostos na ordem natural da operação de modo que cada componente tenha a menor distância possível a percorrer da primeira à última fase.

2. Empregar planos inclinados ou aparelhos concebidos de modo que o operário sempre ponha no mesmo lugar a peça que terminou de trabalhar, indo ela ter à mão do operário imediato por força do seu próprio peso sempre que isso for possível.

3. Usar uma rede de deslizadeiras por meio das quais as peças a montar se distribuam a distâncias convenientes.

O resultado destas normas é a economia de pensamento e a redução ao mínimo dos movimentos do operário, que, sendo possível, deve fazer sempre uma só coisa com um só movimento (Ford, 1964:65).

Em comparação com o taylorismo da prática dos tempos e movimentos individuais, agora com o processo fordista tal prática se dará de forma coletiva, o ritmo de produção deverá ser acompanhado pelo ritmo da esteira, ou do plano inclinado, e não mais pela capacidade do trabalhador, o que implica, por um lado, disciplinamento do tempo do trabalhador e, por outro, impede

\footnotetext{
${ }^{25}$ Assim como Frederick W. Taylor idealizou conteúdos gerenciais que estimularam Henry Ford em sua proposta de produção em massa, Alfred Pritchard Sloam Jr. (1875-1966), na General Motors, complementou as ideias de Ford (Womack et al., 1992:27).
} 
a sua participação e/ou criatividade. A linha de montagem impõe seu próprio e inflexível ritmo, cada ação deve seguir a precedente de acordo com o tempo previsto, identificando, assim, "os princípios fundamentais da mecanização: padronização, continuidade, coação e redução do trabalho a uma simples tarefa" (Hirschhorn, 1984:14).

Em resumo, a esteira mecânica parcela o trabalho, especializa o trabalhador e intensifica suas ações com o objetivo de eliminar os tempos mortos, o que significa dizer que a diferença entre o taylorismo e o fordismo é que as normas de produção são incorporadas, no caso do fordismo, aos dispositivos automáticos das máquinas. Assim, o movimento das máquinas define a operação e o tempo necessário para sua execução.

As implicações do fordismo na organização da produção e do trabalho são de dois tipos:

a) social, à medida que diferencia a concepção da execução, institui normas de supervisão imediata e controla o ritmo de trabalho pela máquina; b) técnico, na medida em que estabelece métodos lineares de trabalho, fragmenta e simplifica operações, usa equipamentos especializados e poucos flexíveis através de linha de montagem ou processos semelhantes (Tenório, 1994:88).

Esse procedimento social e técnico exige uma divisão de trabalho consoante com o taylorismo, no qual o planejamento fica distanciado da execução, e surge um novo tipo de mão de obra, diferente daquele até então.

Profissionais como o engenheiro de produção, ao lado do engenheiro de produtos e de outras especialidades, irrompem no mercado de trabalho em substituição aos antigos donos de oficinas e ao supervisor dos tempos da produção artesanal. O antigo "proprietário operário" fazia de tudo: recebia a encomenda da montadora, projetava a peça, desenvolvia a máquina para fabricá-la e, em muitos casos, supervisionava a operação da máquina na oficina. Já a missão fundamental desses novos especialistas consistia em projetar tarefas, peças e ferramentas que pudessem ser manuseadas pelos trabalhadores desqualificados que formavam o grosso da nova força de trabalho na indústria automobilística.

Nesse novo sistema, o trabalhador do chão de fábrica não tinha uma carreira pela frente, podendo no máximo chegar a supervisor. Mas, nas novas profissões de engenharia, havia uma carreira a ser escalada. Tampouco se limitava a uma só companhia, como teria sido do agrado de Ford (Womack et al., 1992:20-21).

A partir do processo de produção em massa fordista é então possível elaborar grandes quantidades de produtos padronizados sob uma organização 
da produção e do trabalho que emprega matéria-prima, máquinas e equipamentos, desenho e mão de obra estandardizados ao menor custo possível. O objetivo desse modo de gerenciamento foi, portanto, promover a economia de escala a fim de diminuir os custos e ampliar o mercado. A condição para implementar um sistema de produção dessa natureza é a existência de um mercado latente ou planejado para o consumo de massa. Para tanto Ford imaginava que, pagando melhores salários e criando boas condições de trabalho (foi ele quem introduziu o trabalho de oito horas e o salário de cinco dólares por dia), os operários teriam renda e tempo de lazer para consumir os produtos por eles produzidos. A obtenção de mercado pela empresa estaria baseada na obtenção de economias de escala através da verticalização do sistema, desde a matéria-prima à distribuição, e no aumento da velocidade do processo de produção, que passa a ser controlado pelo ritmo da linha de montagem e do movimento das máquinas.

O processo de produção fordista, como modelo ampliado do taylorismo e semelhante a este, não ficou restrito ao ambiente norte-americano, embora este tenha sido o "exportador" do modelo. Inglaterra, Itália, França, Alemanha e Rússia, nos anos 1920, e de maneira mais acentuada após a Segunda Guerra Mundial, empregavam o fordismo como método de gestão empresarial. De acordo com Jeffrey Herf, na Alemanha, "Henry Ford [...] era o apóstolo do gerenciamento científico e das técnicas de linha de montagem", ou reconhecido por alguns teóricos da época como um revolucionário "não menos revolucionário que o próprio capitalismo" (Herf, 1993:55). No Brasil, desde o primeiro período Vargas (1930-45), os princípios fordistas não foram totalmente estranhos, "o capital nacional pôs em prática uma política de substituição de importações - conduzidas pelo Estado - no setor urbano" (Leborgne e Lipietz, 1991:119) e que vai acentuar-se, como paradigma, nos anos 1950, ${ }^{26}$ "associada ao primeiro grande movimento das multinacionais na direção da manufatura no estrangeiro", gerando "uma onda de industrialização fordista competitiva em ambientes inteiramente novos" (Harvey, 1992:135).

Assim, a despeito de opiniões contrárias à existência do fordismo como modo de gestão da produção, somos partidários de que tanto Frederik W. Taylor quanto Henry Ford ${ }^{27}$ (obviamente não esquecendo outras figuras importantes,

\footnotetext{
${ }^{26}$ Exemplo disso é a tese apresentada, em 1949, pelo sociólogo Alberto Guerreiro Ramos, para ocupar o cargo de técnico de administração no então Departamento Administrativo do Serviço Público (Dasp): Guerreiro Ramos (2009).

${ }^{27}$ O suplemento quinzenal "Fortune Américas" (Jornal do Brasil, 1999) elegeu Henry Ford "o empresário do século” XX.
} 
como Henry Fayol, Lílian Gilbreth e Mary Parker Follet, por exemplo) foram figuras centrais na proposição de conceitos e propostas de como melhorar a eficiência dos sistemas sociais organizados sem distinção, se privados ou públicos. ${ }^{28}$ Essa opinião foi extraída da bibliografia corrente sobre o tema gestão da produção bem como daquela que tem interface com o tema, como é o caso, por exemplo, da literatura que discute modos de gestão econômica na qual o conceito de fordismo aproxima-se daquele de Estado de bem-estar social e de keynesianismo.

Portanto, como paradigma organizacional, o fordismo se caracteriza como um modelo de gestão da produção para grandes quantidades de produtos padronizados, o que exige um "consumo de massa, um [...] sistema de reprodução da força de trabalho, uma [...] política de controle e gerência do trabalho, uma [...] estética e uma [...] psicologia, em suma, um [...] tipo de sociedade democrática, racionalizada, modernista e populista" (Harvey, 1992:121).

Citando Antonio Gramsci (1891-1937), David Harvey faz o seguinte comentário sobre a percepção do fordismo por Gramsci:

O americanismo e o fordismo, observou ele em seus Cadernos do cárcere, equivaliam ao "maior esforço coletivo até para criar, com velocidade sem precedentes, e com uma consciência de propósito sem igual na história, um novo tipo de trabalhador e um novo tipo de homem". Os novos métodos de trabalho "são inseparáveis de um modo específico de viver e de pensar e sentir a vida". Questões de sexualidade, de família, de formas de coerção moral, de consumismo e de ação do Estado estavam vinculadas, ao ver de Gramsci, ao esforço de forjar um tipo particular de trabalhador "adequado ao novo tipo de trabalho e de processo produtivo" [...] (Harvey, 1992:121-122). ${ }^{29}$

\subsection{Crise do fordismo}

A oposição ao fordismo como paradigma técnico-organizacional ou técnico-econômico surge de diferentes maneiras entre os anos 1950-60 em países como

\footnotetext{
${ }^{28}$ Ver Guerreiro Ramos (2009), em que a seleção de um candidato ao cargo de técnico de administração no serviço público requeria conhecimentos oriundos desse contexto teórico-organizacional.

29 "Caderno 22 (1934): Americanismo e fordismo" (Gramsci, 2001:241-282). Para uma melhor compreensão dos estudos de Gramsci em relação ao fordismo, ver também Ruy Braga (apud Katz et al., 1995:87-91).
} 
Japão, ${ }^{30}$ Itália, França e EUA através da reação de estudantes, de trabalhadores, de governos, empresários e estudiosos em gestão organizacional. O movimento estudantil articula uma reação político-cultural contra a presença do fordismo na sociedade de então; ${ }^{31}$ os operários rebelam-se contra a monotonia das tarefas rotinizadas da linha de montagem, ${ }^{32}$ através do aumento do absenteísmo - ausência ao trabalho pelos mais diversos motivos, aumento do turnover rotação da mão de obra por diversas empresas, e de baixa qualidade e produtividade - crescimento nos defeitos de fabricação ou no atendimento ao cliente, bem como nos desperdícios de insumos; os governos implementam políticas de austeridade econômica que desmobilizam o Estado de bem-estar; ${ }^{33}$ os empresá-

30 "[...] a partir deste momento (o começo dos anos 50), uma via própria japonesa, de organização e de gestão da produção se põe em curso de se afirmar. Seu traço central e distintivo, em relação à via taylorista norte-americana, é que em lugar de proceder através da destruição dos saberes operários complexos e da decomposição em gestos elementares, a via japonesa vai avançar pela desespecialização dos profissionais para transformá-los não em operários parcelares, mas em plurioperadores, em 'trabalhadores multifuncionais', como dirá Monden (1983)" (Coriat, 1994:53, grifos do autor).

31 "[...] o movimento estudantil dos anos sessenta foi o grande articulador da crise político-cultural do fordismo e a presença nele, bem visível, de resto, da crítica marcusiana é expressão da radicalidade da confrontação que protagonizava. São três as facetas principais dessa confrontação. Em primeiro lugar, opõe ao produtivismo e ao consumismo uma ideologia antiprodutivista e pósmaterialista. Em segundo lugar, identifica as múltiplas opressões do quotidiano, tanto ao nível da produção (trabalho alienado), como da reprodução social (família burguesa, autoritarismo da educação, monotonia do lazer, dependência burocrática) e propõe-se alargar a elas o debate e a participação políticos. Em terceiro lugar, declara o fim da hegemonia operária nas lutas pela emancipação social e legitima a criação de novos sujeitos sociais de base transclassista" (Souza Santos, 1995:249).

${ }^{32}$ Semelhante a Chaplin com o filme Tempos modernos, Elio Petri dirigiu, em 1971, A classe operária vai ao paraíso, filme que critica o processo taylorista-fordista de produção fabril vigente na Itália. No Brasil, essa reação foi identificada por Márcia Paula Leite que diz: "O aspecto fundamental a ser recuperado nesse processo consiste no fato de que, a partir das greves de 1978, não só a 'abertura' política que se vinha desenvolvendo desde meados da década ganhou um novo impulso, como o padrão vigente de consumo da mão de obra industrial foi profundamente questionado pelos trabalhadores, num movimento em que desempenharam papel importante as demandas relacionadas às condições e relações de trabalho". A seguir a autora cita algumas dessas reivindicações: "relativas à disciplina de trabalho, ritmos e cadências impostos pelas empresas; critérios de demissão, recrutamento e promoções, escalas salariais; autoritarismo das chefias, horas extras e estabilização da mão de obra" (Leite, 1994:141).

${ }^{33}$ A reação ao Estado de bem-estar ficou bem marcada pelos governos de Margaret Thatcher, na Inglaterra, em 1979, e Ronald Reagan nos Estados Unidos, em 1981. Essa reação provoca o ressurgimento do liberalismo ou, como tem sido chamado, neoliberalismo, que identifica o poder público como ineficaz na solução dos problemas estruturais das sociedades. Possivelmente esta leitura tenha sido revista a partir dos acontecimentos financeiros ocorridos no final do ano de 
rios reagem à diminuição do lucro, causada pela desaceleração da produtividade e do crescimento da relação capital/produto, com a internacionalização da produção; e os estudiosos em sistemas organizacionais, a partir dos enfoques comportamental e sistêmico, procuraram mostrar a necessidade de as organizações, para sua sobrevivência, interagirem com o ambiente.

Portanto, o paradigma gerencial fordista foi posto em questão, ${ }^{34}$ novas formas em gestão da produção são exploradas e apresentadas como uma necessidade tecnológica na qual a substituição do fordismo é justificada por uma destruição criadora a la Schumpeter. Podemos resumir essa crise através de quatro descrições analíticas do fenômeno, respectivamente a de Alain Lipietz com Daniele Leborgne, a de Paulo Fleury com Rabecca Arkader, Cláudio Salvatori Dedecca e Ruy Braga:

Primeiro, uma crise latente do paradigma industrial (antes os autores já comentam que essa crise não se restringiu a tal setor [grifo meu]), como uma desaceleração da produtividade e um crescimento da relação capital/produto, conduziu a uma queda da lucratividade nos anos 60. A reação dos empresários (via internacionalização da produção) e do Estado (generalização das políticas de austeridade) levou a uma crise do emprego e daí à crise do Estado-previdência. A internacionalização e a estagnação dos rendimentos detonaram por sua vez a crise "do lado da demanda", no fim dos anos 70. A "flexibilidade" surgiu então como uma adaptação a este último aspecto da crise, que é tão fundamental quanto o aspecto "lucratividade" (LEBORGNE \& LIPIETZ, 1988:16).

As causas do declínio foram atribuídas a cinco conjuntos de filosofias e práticas gerenciais: i) estratégias ultrapassadas, fortemente influenciadas pelos princípios da produção em massa e por um arraigado paroquialismo; ii) tendência a uma ênfase exagerada nos aspectos de curto prazo, em prejuízo do longo prazo; iii) fragilidade tecnológica no que diz respeito ao desenvolvimento de produtos e processos; iv) negligência com os recursos humanos, principalmente no que diz respeito ao chão de fábrica; v) falhas generalizadas na cooperação, tanto interna quanto externa, vertical e horizontalmente (Castro et al., 1996:259).

\footnotetext{
2009 quando, na realidade, foi o Estado por meio de recursos públicos que "salvou" as finanças do sistema financeiro, principalmente do norte-americano.

${ }^{34}$ Em abril de 1973, em relatório sobre política social da então denominada Comunidade Econômica Europeia (CEE), hoje União Europeia (EU), recomendava-se a eliminação do trabalho sob linha de montagem (Durand, 1978:72)
} 
Os argumentos apresentados para justificar — positiva ou negativamente - o processo de flexibilização das relações de trabalho estão relacionados às características particulares que marcam a atual crise econômica e a certas particularidades do padrão de estruturação das relações de trabalho no pós-guerra. A financeirização do capital industrial, em um contexto de crescente instabilidade econômica e de globalização financeira, e a disponibilidade de novas tecnologias e métodos organizacionais desestabilizaram, a partir da segunda metade dos anos 60, os padrões de concorrência intercapitalista vigentes nos mercados nacionais e internacionais (Mattoso e Oliveira, 1996:58).

A crise do fordismo apresenta-se como a crise de um modo de organização do trabalho, manifesta no endurecimento da luta de classes na produção. Questionando as condições de trabalho ligadas à fragmentação e à intensificação das tarefas, estas lutas apontariam para os limites da alta da taxa da mais-valia inerentes às relações de produção. Daí a necessidade imperiosa da transição ao neofordismo. Saída durável para a crise, o novo regime implicaria uma total modificação das modalidades da luta de classes, decorrente das metamorfoses da estratificação inerente a cada uma das classes polarizadas pela relação salarial (Aglieta apud Braga, 2003:51).

Embora "ainda esteja no limiar da discussão contemporânea, existe a possibilidade de as relações de comando - uma característica profundamente estabelecida e aceita da empresa industrial desde a Revolução Industrial e o nascimento da economia clássica - estarem obsoletas. [...] Eis, portanto, o destino da Revolução Keynesiana", diríamos, do fordismo, que, como "tantas outras coisas na economia" e na gestão da produção, "foi boa para sua época; mas teria inevitavelmente que sofrer com o passar do tempo. Pois o tempo revelou uma assimetria política e uma dinâmica microeconômica num mundo altamente organizado para as quais" o keynesianismo-fordismo "não tem mais nada a dizer" (Galbraith, 1989:252-3). Paulo B. Tigre conclui (1993:29):

O remédio keynesiano [...] não se mostrou eficaz nos anos 80 , pois a natureza da crise estava justamente no esgotamento do modelo de produção em massa, apoiado no uso intensivo de energia e matérias-primas. Um novo paradigma técnico-econômico entrava em cena, envolvendo não apenas novas tecnologias e práticas produtivas, mas também novo arcabouço institucional, regulatório e até mesmo novas teorias econômicas.

A transição do modelo de racionalização de trabalho rígido para um mais flexível se dá sob três "gerações": a primeira geração a partir da proposta taylo- 
rista-fordista-fayolista; a segunda geração a partir da Escola de Relações Humanas, associada posteriormente às demais ciências sociais que predominaram no mundo dos negócios até o final dos anos 1960;35 a terceira geração de racionalização do trabalho vai coincidir com o advento das técnicas japonesas de gestão da produção (Valle e Peixoto, 1994:2-3) e com o desenvolvimento acelerado de novas tecnologias da informação e equipamentos de base microeletrônica.

Semelhante ao fordismo, as tecnologias de terceira geração, que também transcendem o setor industrial, operacionalizam-se através de uma organização política e social e de um novo modo de produção capitalista, a acumulação flexível, que é referenciado pelo confronto direto com a rigidez do fordismo. Esse modo de produção

se apoia na flexibilidade dos processos de trabalho, dos mercados de trabalho, dos produtos e padrões de consumo. Caracteriza-se pelo surgimento de setores de produção inteiramente novos, novas maneiras de fornecimento de serviços financeiros, novos mercados e, sobretudo, taxas altamente intensificadas de inovação comercial, tecnológica e organizacional (Harvey, 1992:140).

Esse novo modo de organização da produção e do trabalho é uma tentativa de se caminhar para um modelo de gestão organizacional que privilegie a flexibilização interna e externa à empresa, em relação a um contexto internacional que percebeu o esgotamento do taylorismo-fordismo e que se assenta na tríade globalização da economia, progresso científico-técnico e valorização da cidadania (Tenório, 2000).

Na realidade, parece que este paradigma ainda está em transição, na medida em que a flexibilização organizacional comporta-se como a trajetó-

\footnotetext{
${ }^{35}$ Essa "segunda geração" estaria submetida àquilo que Alberto Guerreiro Ramos denominou, criticamente, "síndrome comportamentalista", tema do capítulo 3 do seu livro A nova ciência das organizações: uma reconceituação da riqueza das nações. Esse autor conclui o citado capítulo da seguinte forma: "Por impressionante que se afigurem os traços básicos do comportamento, deve-se compreender que os mesmos não estão afetando remotamente a vida das pessoas. Na realidade, constituem o credo não enunciado de instituições e organizações que funcionam na sociedade centrada no mercado. Para ter condições de enfrentar os desafios de uma tal sociedade, a maioria de seus membros interioriza a síndrome comportamentalista e seus padrões cognitivos. Essa interiorização ocorre, geralmente, sem ser notada pelo indivíduo, e assim a síndrome comportamentalista transforma-se numa segunda natureza. A disciplina administrativa padrão, ela própria admitindo que os seres humanos são individualistas fluidos, e capturada pelos pressupostos do perspectivismo, do formalismo e do operacionalismo, não pode ajudar o indivíduo a superar essa situação" (Guerreiro Ramos, 1981:67).
} 
ria de uma situação fordista para outra, pós-fordista. Essa situação pode ser observada na medida em que as decisões centram-se na polarização produtividade-flexiblidade ou padronização-personalização, na qual as expressões produtividade e padronização são os pares da busca da eficiência empresarial. No entanto, com o advento das tecnologias da informação, os pares que importam são flexibilidade-personalização, já que eles promovem uma nova lógica gerencial sob a qual a diferenciação importa mais que a padronização. Portanto, é a partir desses pares que interpretaremos o pós-fordismo como método referencial de gestão da produção.

\section{Pós-fordismo}

Como já havíamos definido na introdução deste texto, o pós-fordismo ou modelo flexível de gestão organizacional, caracteriza-se pela diferenciação integrada da organização da produção e do trabalho sob a trajetória de inovações tecnológicas em direção à democratização das relações sociais nas organizações. Concepção que contraria a fordista na medida em que esta se baseia na previsão de um mercado em crescimento, o que justificava o uso de equipamentos especializados a fim de obter economia de escala. Agora surgem equipamentos flexíveis cuja finalidade é atender a um mercado diferenciado, tanto em quantidade quanto em composição. Segundo as concepções de Martin Boddy e de Paulo Fleury com Rebecca Arkader, a seguir apresentadas, o novo paradigma de gestão da produção distingue-se do anterior na medida em que:

O sistema pós-fordista de produção se caracteriza, sobretudo, pela sua flexibilidade. [...] Os mercados são cada vez mais volúveis e imprevisíveis. [...] A empresa individual, portanto, põe ênfase na flexibilidade, na sua capacidade de reagir a, e de procurar mudanças de mercado. A flexibilidade se manifesta de várias formas: em termos tecnológicos; na organização da produção e das estruturas institucionais; no uso cada vez maior da subempreitada; na colaboração entre produtores complementares. À flexibilização na produção corresponde uma flexibilização dos mercados de trabalho, das qualificações e das práticas laborais (Boddy, 1990:46).

Os novos padrões emergentes foram agrupados em seis características básicas: i) um esforço permanente para a melhoria simultânea da qualidade, dos 
custos e dos serviços de entrega; ii) manter-se muito próximo dos clientes, para entender suas necessidades e ser capaz de se adaptar para satisfazêlas; iii) busca de uma maior aproximação com os fornecedores; iv) utilização estratégica da tecnologia, visando à obtenção de vantagens competitivas; v) utilização de estruturas organizacionais mais horizontalizadas e menos compartimentalizadas; vi) utilização de políticas inovadoras de recursos humanos (Castro et al., 1996:259).

No livro La flexibilidad del trabajo en Europa, coordenado por Robert Boyer e sob os auspícios da Federación Europea de Investigaciones Económicas (Fere), é feito o seguinte comentário:

Arriscando caricaturizar as coisas, poderíamos dizer que a figura emblemática dessa forma de organização industrial seria a fábrica flexível, amplamente automatizada e que incorpora em seu próprio princípio de organização uma variabilidade mais ou menos completa ao volume e à definição dos produtos requeridos pelos mercados (Boyer, 1986:278).

O autor identificou nessa publicação da Fere cinco definições para o termo flexibilidade: a) maior ou menor adaptabilidade da organização da produção - opções técnicas e organizacionais condicionadas às dimensões e demandas do mercado; b) a atitude dos trabalhadores para mudar de posto de trabalho - competência técnica e atitude da mão de obra para dominar diversos segmentos de um mesmo processo produtivo; c) debilidade das restrições jurídicas que regulam o contrato de trabalho - dizem respeito aos aspectos institucionais relacionados às leis trabalhistas e que facilitem, inclusive, ao empregador a dispensa dos empregados sem qualquer garantia adicional; d) sensibilidade dos salários (nominais ou reais) — significa a dependência dos salários em relação à situação econômica da empresa ou ao mercado de trabalho em geral; e) possibilidade de as empresas subtraírem uma parte das deduções sociais e fiscais - liberação das empresas das regulações do Estado quanto a seu funcionamento.

Esse novo modelo é implementado não mais sob a base de equipamentos ou processos mecânicos e lineares de produção, mas de sistemas eletrônicos que flexibilizam o processo produtivo das organizações com o objetivo de atender às diferentes demandas de um mercado cada vez mais seletivo em quantidade e qualidade. De acordo com Benjamin Coriat, esse novo processo de produção apoia-se em três princípios interdependentes: 
- distribuir o trabalho não mais em postos individuais e tarefas fragmentadas, mas sim em pequenas "ilhas" [células] de trabalhadores, em pequenos grupos que administram um conjunto homogêneo de tarefas; ${ }^{36}$

- romper o caráter unidimensional das linhas de montagem e de fabricação, para conceber a oficina como uma rede de minilinhas entre as quais circula o produto seguindo trajetórias que se tornam complexas;

- finalmente, substituem a linha transportadora de ritmo por carretilhas que se deslocam pela rede com ritmos flexíveis, e capazes de selecionar - graças a um sistema guiado por cabos - , no que concerne a tarefas-padrão, colocando nas linhas correspondentes, ou no tocante a tarefas específicas, de encaminhar-se até as partes da rede especialmente concebidas para elas. Em poucas palavras, passamos de linhas unidimensionais de ritmo a organizações multidimensionais, em rede a ritmos flexíveis (Coriat, 1993:22).

Tal modelo de gestão da produção não está sendo implementado, como já observamos, exclusivamente no setor secundário. Ele é também reproduzido no setor terciário ou nos espaços técnico-administrativos das empresas fabris. Fato que pode ser percebido nos próprios processos produtivos dos escritórios. "Num escritório, a padronização, a atualização de dados em tempo real e a armazenagem ordenada do histórico das transações possibilitadas pelos computadores reforçam o controle e a continuidade das funções do escritório" (Zuboff, 1994:82).

Em uma estrutura de produção com essa nova configuração tecnológica, em rede ou não de equipamentos microeletrônicos, ${ }^{37}$ ajustes podem ser feitos em pouco espaço de tempo para atender a diferentes demandas de serviços ou produtos. Sob o modelo taylorista-fordista de automação rígida, cuja base

\footnotetext{
36 "Muitos sociólogos contrapõem o parcelamento individual de tarefas — próprio do 'gerenciamento científico' [taylorismo] — à organização grupal em 'círculos de qualidade', que caracteriza o pós-taylorismo. Sem dúvida, Perrin demonstra que esse contraste é fictício em todos os casos em que subsiste a cadeia de montagem. É a forma de supervisão patronal, que passa do controle individual ao coletivo, a única coisa que se altera com estas reconversões. Frequentemente, os 'grupos autônomos' coexistem com a fabricação fragmentária tradicional, conformando um esquema justaposto de pessoas e grupos submetidos à mesma subordinação departamental e ao mesmo controle gerencial do passado. A sequência despótica dos ritmos e movimentos que Taylor implantou desenvolveu-se aqui mediante sofisticados sistemas computadorizados" (Katz et al., 1995:31-32).

${ }^{37} \mathrm{Na}$ cronologia histórica da flexibilização técnica e/ou organizacional, que começa com o surgimento dos microcomputadores no início dos anos 1970, esses equipamentos vão desempenhar um papel fundamental no processo produtivo do terciário.
} 
técnica é mecânica ou eletromecânica, ${ }^{38}$ existiam nos sistemas de apoio administrativo, por exemplo, os seguintes tipos de mão de obra: trabalhadores especializados em escrever à máquina (datilógrafos), trabalhadores especializados em operar máquinas contábeis (mecanógrafos), trabalhadores especializados em manejar máquinas impressoras (tipógrafos) etc. Hoje, com a flexibilização técnica de base microeletrônica, ${ }^{39}$ ou de automação flexível, uma só pessoa pode operar (ajustar) um equipamento (p. ex.: um microcomputador) que está apto, através de diferentes programas (softwares), a produzir, por exemplo, textos, registros contábeis, editoração, desenhos. A flexibilização do sistema bancário é um exemplo típico desse novo modelo no setor terciário. O contato do cliente com o balcão de serviços (p. ex., com o caixa) tende a diminuir na medida em que equipamentos eletrônicos atendem, praticamente, a todas as demandas de rotina de um banco.

Tenório e Palmeira (2002:75) apontam que "as práticas laborais, a divisão do trabalho e a especialização do trabalhador" típicas no sistema taylorista-fordista, são alteradas no modelo pós-fordista uma vez que neste a "polivalência da mão de obra são suas principais características". E a "descentralização-polivalência significa flexibilizar a organização do trabalho por meio dos seguintes princípios":

v Divisão maleável e integração de funções de concepção, controle e execução;

v Definição de tarefas de acordo com as circunstâncias e necessidades;

v Integração de tarefas para criar um trabalho completo identificável com resultados visíveis;

v Privilégio ao trabalho em equipe, com forte incentivo para o indivíduo e/ou o grupo programar, com independência, seu trabalho e determinar os procedimentos relativos à execução de tarefas;

v Desenvolver nos empregados a capacidade de prever problemas e incentivar soluções criativas;

v Realização de tarefas e funções em grupos de trabalho;

v Mão de obra qualificada com características multifuncionais e com múltiplas habilidades;

\footnotetext{
${ }^{38}$ Os equipamentos com essa base técnica não podem ser alterados no tipo ou nas etapas do processo de produção. Demandas diferenciadas ficarão dependentes de um novo equipamento.

39 Os equipamentos com essa base técnica podem ser alterados na medida em que aceitam mudanças em sua programação. Demandas diferenciadas não ficarão dependentes de um novo equipamento.
} 
v Informações claras sobre os resultados obtidos no trabalho;

v Autocontrole (Tenório e Palmeira, 2002:75-76).

A propósito do uso pelo setor terciário da tecnologia produzida pelo setor secundário, Mário Sérgio Salerno comenta que a indústria de transformação "é produtora de inovações organizacionais, e que exporta paradigmas para outras áreas da economia — da mesma forma como se falava nos anos 60 em 'taylorismo' nos escritórios e bancos, fala-se hoje em 'just in time' bancário" (Salerno, 1994:21). Passadas já algumas décadas desde os anos 1970, esse processo de mudança continua no início do século XXI atingindo, simultaneamente, aspectos técnicos, econômico-financeiros, organizacionais e de relações sociais nos mais diferentes setores produtivos (agrícola, industrial ou de serviço, público ou privado) promovendo uma nova divisão social do trabalho. Divisão de trabalho que, engendrada pelo conjunto da tecnologia da informação (TI) - hardware e software, tem protagonizado significados como fábrica de software, fábrica que parece ser administrada entre o continuum: fordismo (0) - (1) pós-fordismo. No entanto, no que diz respeito às relações de trabalho, a referência pós-fordista

transformaria a força de trabalho, tanto do ponto de vista hierárquico quanto do ponto de vista espacial, acabando por romper o quadro da contratação coletiva. Com o ritmo da acumulação intensificado, uma perspectiva de longo prazo para um capitalismo politicamente estável e sem opositores seria reinaugurada. O operário pós-fordista [...] aparece como um indivíduo atomizado, flexível, tendencialmente dessindicalizado, mantido com salário baixo e irremediavelmente precarizado no posto de trabalho. O Estado não mais asseguraria a cobertura dos custos materiais da reprodução da força de trabalho, favorecendo a contenção do consumo. As metamorfoses do salariado explicariam, nesse sentido, a crise de transição [entre o fordismo e o pós-fordismo] (Braga, 2003:107).

\section{Conclusão}

Poderíamos concluir este ensaio com as seguintes frases: "nada de novo no ar a não ser os aviões da Panair", ou "mais velho do que a Sé de Braga" ou, ainda, "que coisa mais antiquada!". E, se quisermos ser otimistas, empregaríamos quase todos os antônimos possíveis do adjetivo novo: ancestral, anoso, antigo, antiquado, arcaico, avelhantado, avelhentado, bolorento, borocoxô, 
broco, caduco, cansado, carcomido, decrépito, embolorado, encanecido, envelhecido, gagá, gasto, idoso, longevo, macróbio, maduro, matusalênico, obsoleto, passado, primevo, primitivo, prisco, provecto, senil, velho, velhusco, veterano, vetusto (Houaiss, 2003). Por quê? Por que falar de fordismo e pósfordismo, principalmente do primeiro quando Taylor e Ford seriam os jurássicos do pensamento organizacional, interpretação que desde os anos 1960 do século passado já escutávamos nos cursos de graduação em administração e assemelhados?

O retorno a Taylor e Ford, notadamente fazendo o contraponto com o denominado pós-fordismo de final do século passado, faz sentido uma vez que a tese que aqui defendemos é a existência de uma combinação tecnológica oriunda de um e outro paradigma. Isto é, os processos produtivos, de bens ou de serviços, ainda carecem de argumentos que justifiquem a produtividade através do ajuste, do arranjo, de métodos protagonizados pelo taylorismo-fordismo, como daqueles surgidos com o advento da tecnologia de base microeletrônica e/ou da tecnologia de informação. Portanto, desconciliar o fordismo do pós-fordismo é não compreender os processos de organização da produção na nossa contemporaneidade. De outro, é transmitir conhecimentos que procuram legitimar, apenas, o que está de moda. "Mcdonaldização" (Ritzer, 1993) e "fábrica de software" (Fernandes e Teixeira, 2004) são exemplos de expressões que justificam o conhecimento daquilo que foi pioneiro — o taylorismo-fordismo, o precursor no gerenciamento da organização da produção e do trabalho.

O intento de interpretar esta tese dispondo-a em um continuun no qual os dois paradigmas "conversariam" apesar das suas contradições — fordismo — pós-fordismo — , demonstra que a unidade dos contrários, como toda a dialética, é um saber não dispensável, como sempre pretenderam os positivistas e/ou funcionalistas de turno, aqueles que pretendem entender as relações produtivas no interior das organizações e destas com a sociedade como se consequências fossem. Aqui, propositalmente, prescindimos da relação organização-mercado uma vez que é nesta referência relacional que tem predominado o modismo, a mão de via única, o pós-fordismo, no estudo e prática do pensamento organizacional contemporâneo. Nossa percepção, que para muitos estaria entre o Triássico e abaixo do Cretáceo, é consciente da necessidade de não desconhecer a história, possivelmente o único saber cujas lembranças têm valor como previsão, como planejamento. "É assim que a história toma parte nas ciências, em que a aplicação constata a cada instante a sua utilidade" (Honoré de Balzac, apud Benjamin, 2006:791). 
A moda é a procura sempre vã, muitas vezes ridícula, às vezes perigosa, de uma beleza superior ideal (Du Camp, apud Benjamin, 2006:104).

\section{Referências}

BENJAMIN, Walter. Passagens. Belo Horizonte: Editora UFMG; São Paulo: Imprensa Oficial do Estado de São Paulo, 2006.

BODDY, Martin. Reestruturação industrial, pós-fordismo e novos espaços industriais: uma crítica. In: VALLADARES, L.; PRETECEILLE, E. (Org.). Reestruturação urbana: tendências e desafios. São Paulo: Nobel/Iuperj, 1990. p. 44-58.

BORNHEIM, Gerd A. Dialética: teoria, práxis. Porto Alegre: Editora Globo; São Paulo: Edusp, 1977.

BOYER, Robert (Coord.). La flexibilidad del trabajo en Europa: un estudio comparativo de las transformaciones del trabajo asalariado en sete países, entre 1973 e 1985. Madrid: Ministério de Trabajo y Seguridad Social, 1986.

BRAGA, Ruy. A nostalgia do fordismo: modernização e crise na teoria da sociedade salarial. São Paulo: Xamã, 2003.

BRAVERMAN, Harry. Trabalho e capital monopolista: a degradação do trabalho no século XX. Rio de Janeiro: Zahar, 1977.

CARAVANTES, Geraldo Ronchetti. Teoria geral da administração: pensando \& fazendo. Porto Alegre: AGE, 1998.

CASTRO, Antonio de Barros de et al. Estratégias empresariais na indústria brasileira: discutindo mudanças. Rio de Janeiro: Forense Universitária, 1996.

CHÂTELET, François. História da filosofia: ideias, doutrinas. Rio de Janeiro: Zahar Editores, 1973. v. 1.

CHIAVENATO, Idalberto. Teoria geral da administração. São Paulo: McGraw-Hill, 1979. v. 1 e 2 .

CORIAT, Benjamin. El taller y el robot: ensayos sobre el fordismo y la producción en masa en la era de la electrónica. 2. ed. Madrid: Siglo Veintiuno, 1993.

CORIAT, Benjamin. Pensar pelo avesso: o modelo japonês de trabalho e organização. Rio de Janeiro: Revan/UFRJ, 1994. 
DAL ROSSO, Sadi. Mais trabalho!: a intensificação do labor na sociedade contemporânea. São Paulo: Boitempo, 2008.

d'HONDT, Jacques. Hegel. Lisboa: Edições 70, 1984.

DICTIONARY of national biography. Disponível em: <www.oxforddnb.com $>$. Acesso em: 3 maio 2011.

DURAND, Claude. Le travail enchainé. Paris: Seuil, 1978.

FERNANDES, A.A.; TEIXEIRA, D.S. Fábrica de software: implantação e gestão de operações. São Paulo: Atlas, 2004.

FERREIRA, Cândido et al. Alternativa sueca, italiana e japonesa ao paradigma fordista: elementos para uma discussão sobre o caso brasileiro. In: SEMINÁRIO ABET, Associação Brasileira de Estudos do Trabalho, 1991.

FINZI, Roberto. Lênin, Taylor, Stakhanov: o debate sobre a eficiência econômica após Outubro. In: HOBSBAWN, Eric (Org.). História do marxismo: o marxismo na época da terceira internacional: a URSS da construção do socialismo ao stalinismo. Rio de Janeiro: Paz e Terra, 1986. p. 137-157.

FORD, Henry. Os princípios da prosperidade: minha vida e minha obra. São Paulo/ Rio de Janeiro: Freitas Bastos, 1964.

GALBRAITH, John Kenneth. O pensamento econômico em perspectiva: uma história crítica. São Paulo: Pioneira/Edusp, 1989.

GRAMSCI, Antonio. Cadernos do cárcere, volume 4. Rio de Janeiro: Civilização Brasileira, 2001.

GUERREIRO RAMOS, Alberto. A nova ciência das organizações: uma reconceituação da riqueza das nações. Rio de Janeiro: FGV, 1981.

GUERREIRO RAMOS, Alberto. Uma introdução ao histórico da organização racional do trabalho. 2. ed. Brasília: Conselho Federal de Administração, 2009.

HARVEY, David. Condição pós-moderna. São Paulo: Loyola, 1992.

HEGEDÜS, András. A contrução do socialismo na Rússia: o papel dos sindicatos, a questão camponesa, a Nova Política Econômica. In: HOBSBAWN, Eric. (Org.). História do marxismo: o marxismo na época da terceira internacional: a URSS, da construção do socialismo ao stalinismo. Rio de Janeiro: Paz e Terra, 1986.

HELOANI, Roberto. Organização do trabalho e administração: uma visão multidisciplinar. São Paulo: Cortez, 1994.

HERF, Jeffrey. O modernismo reacionário: tecnologia, cultura e política na República de Weimar e no 3ํReich. São Paulo: Ensaio; Campinas: Unicamp, 1993. 
HIRSCHHORN, Larry. Beyond mechanization. Massachusetts: MIT Press, 1984.

HOBSBAWN, Eric (Org.). História do marxismo: o marxismo na época da terceira internacional: a URSS da construção do socialismo ao stalinismo. Rio de Janeiro: Paz e Terra, 1986.

HOUAISS, Antonio. Dicionário Houaiss de sinônimos e antônimos da língua portuguesa. Rio de Janeiro: Objetiva, 2003.

JAPIASSU, Hilton; MARCONDES, Danilo. Dicionário básico de filosofia. Rio de Janeiro: Jorge Zahar, 1990.

KANIGEL, Robert. Frederick Winslow Taylor and the enigma of efficiency. New York: Viking Penguin, 1997.

KATZ, Cláudio et al. Novas tecnologias: crítica da atual reestruturação produtiva. São Paulo: Xamã, 1995.

LEBORGNE, Daniele; LIPIETZ, Alain. O pós-fordismo e seu espaço. Espaço \& Debate, v. 8, n. 25 , p. 12-28, 1988.

LEBORGNE, Daniele; LIPIETZ, Alain. As relações capital-trabalho no limiar do século XXI. In: Ensaios FEE, Porto Alegre, v. 12, n. 1, p. 101-130, 1991.

LEITE, Márcia de Paula. O futuro do trabalho: novas tecnologias e subjetividade operária. São Paulo: Scritta, 1994.

LODI, João Bosco. História da administração. São Paulo: Livraria Pioneira Editora, 1971.

MATTOSO, Jorge; OLIVEIRA, Carlos Alonso B. de (Org.). Crise e trabalho no Brasil, modernidade ou volta ao passado? São Paulo: Scritta, 1996.

MEYERS, Fred E. Motion and time study: improving work methods and management. New Jersey: Regente/Prentice-Hall, 1992.

MORAES NETO, Benedito Rodrigues de. Marx, Taylor, Ford: as forças produtivas em discussão. São Paulo: Brasiliense, 1989.

MOTTA, Fernando C. Prestes. Teoria geral da administração: uma introdução. 7. ed. rev. e ampl. São Paulo: Pioneira, 1979.

MOTTA, Fernando C. Prestes. Teoria das organizações: evolução e crítica. São Paulo: Pioneira, 1986.

PRESSMAN, R.S. Software engineering: theory and practice. Upper Saddle River, New Jersey: Prentice-Hall, 2001.

RITZER, Alan. The McDonaldization of society. Pine Forge Press, 1993. 
SALERNO, Mário Sérgio. Modelo japonês, trabalho brasileiro. In: HIRATA, Helena (Org.). Sobre o "modelo" japonês. São Paulo: Edusp, 1993.

SALERNO, Mário Sérgio. Mudança organizacional e trabalho direto em função de flexibilidade e performance da produção industrial. Produção, Belo Horizonte, v. 4, n. 1, p. 5-22, jul. 1994.

SMITH, Adam. A riqueza das nações: investigação sobre sua natureza e suas causas. São Paulo: Abril, 1983. (Os economistas)

SOUZA, José Cavalcante de. Os pré-socráticos: fragmentos, doxografia e comentários. São Paulo: Abril Cultural, 1973. (Os pensadores; v. I)

SOUZA SANTOS, Boaventura. Pela mão de Alice: o social e o político na pós-modernidade. São Paulo: Cortez, 1995.

TAYLOR, Frederick Winslow. Princípios de administração científica. Rio de Janeiro: Presidência da República-DASP, 1948.

TENÓRIO, Fernando G. A flexibilização da produção significa a democratização do processo de produção? In: ENCONTRO ANUAL DA ANPAD 18o, 1994, Curitiba. Anais... Curitiba, 1994. v. 9.

TENÓRIO, Fernando G. Flexibilização organizacional: mito ou realidade. Rio de Janeiro: Editora FGV, 2000.

TENÓRIO, Fernando G.; PALMEIRA, Jorge N. Flexibilização organizacional: aplicação de um modelo de produtividade total. Rio de Janeiro: Editora FGV, 2002.

TENÓRIO, Fernando G.; PALMEIRA, Jorge N. A flexibilização da produção significa a democratização do processo de produção? In: TENÓRIO, Fernando G.; PALMEIRA, Jorge N. Tem razão a administração?: ensaios de teoria organizacional. 3. ed. rev. e ampl. Ijuí: Editora Unijuí, 2008.

TIGRE, Paulo B. Informática como base técnica do novo paradigma. São Paulo em Perspectiva, São Paulo, v. 7, n. 4, p. 26-33, out./dez. 1993.

VALLE, Rogério; PEIXOTO, José A. Certificação da qualidade e opções organizacionais: histórico e estudo de caso no Brasil. In: ENCONTRO ANUAL DA ANPOCS, XVIII, 1994, Caxambu. Anais... p. 1-25.

VERGARA, Sylvia C.; CALDAS, Miguel P. Paradigma interpretacionista: a busca da superação do objetivismo funcionalista nos anos 1980 e 1990. Revista de Administração de Empresas, São Paulo, v. 45, n. 4, p. 66-72. out./dez. 2005.

VERGARA, José Maria. La organización científica del trabajo: ciencia o ideologia? Barcelona: Fontanella, 1971. 
WAHRLICH, Beatriz Marques de S. Reforma administrativa na era Vargas. Rio de Janeiro: FGV, 1983.

WOMACK, James P. et al. A máquina que mudou o mundo. Rio de Janeiro: Campus, 1992.

ZUBOFF, Shoshana. Autonomizar/informatizar: as duas faces da tecnologia inteligente. Revista de Administração de Empresas, São Paulo, v. 34, n. 6, p. 80-91, nov./dez. 1994. 